Vol. 4, No. 1, January 2016

Jurnal llmial

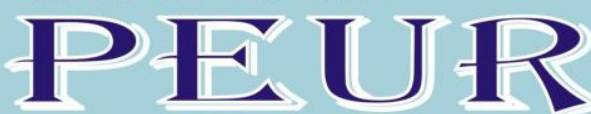

Media Kajian Ilmiah Sosial, Politik, Hukum, Agama dan Budaya
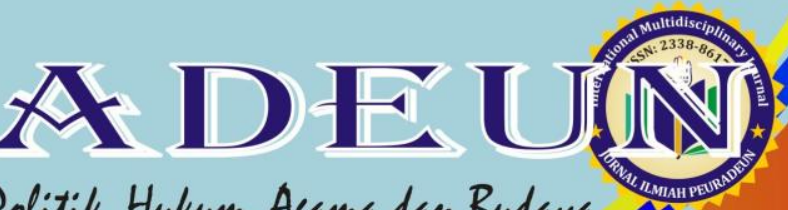


\title{
ISLAMIC APPROACH TO THE ENVIRONMENT AND THE ROLE'S IN THE ENVIRONMENT PROTECTED
}

\author{
Meraj Ahmad Meraj \\ Assistant Professor Department of Arabic Aliah University, Kolkata, India \\ E-mail:merajjnu@gmail.com
}

Received: Nov 30, 2015

Accepted: Dec 5, 2015

Published: Jan 21, 2016

Article Url: https://journal.scadindependent.org/index.php/jipeuradeun/article/view/81

\begin{abstract}
The paper studies the Islamic viewpoint about the environment. Environment holds a central position in most of the discussions of development strategies in the contemporary globalizes world. This is why that deteriorating environment is adversely affecting human lives and is a potential danger for future generations. Today, the environmental crisis endangers human being, other living organism and the natural world alike. How should human behave towards the natural environment is remained most important. Technological solution has not been resulting in satisfying outcome. Discussing the role of the Islamic principles of unity, trustee and responsibility, the Quranic teachings may enhance the environmental consciousness among the people which enable them to establish friendly relationship between God, humankind and nature. In this respect, this paper is a humble attempt to understand the Islamic approach to the environment to explore various conceptual dimensions of environmental security and the possible role of Islam in protecting the environment for the broader benefit of humanity. This paper will also discuss the Islamic principles of human behavior to deal with the nature and environment.
\end{abstract}

Keywords: Environment, Natural Order, Islamic Approach, Quran, Prophetic Tradition 


\section{A. Introduction}

The word "environment" and its' synonym "surroundin gs", represents all conditions, circumstances and influences affecting the development of an organism. It particularly includes every living thing like human beings, animals and plants and non-living thing i.e. soil, water, light, climate temperature and pressure etc. found on our planet' (Khalid, 1998). Environment holds a central position in most of the discussions of development strategies in the contemporary globalizes world. This is why that deteriorating environment is adversely affecting human lives and is a potential danger for future generations. This is the reason that the basic question of human survival on an environmentally fragile planet has gained urgency.

Environment is one of the most serious problems. It is a problem that threatens not only us but the whole world, and future generations and their right to live in a healthy environment. It is therefore causing humanity to approach the 21st century in a state of anxiety. The environmental problem emanates from violation of these constraints. In other words, the excessive use of the environmental resources and waste products are two basic causes responsible for the emergence of the problem. Therefore, the Islamic approach to environmental balance explicitly takes cognizance of these causes and suggests appropriate institutional arrangements for solving the problem.

Environment refers to the complex of physical, chemical and biological factors affecting human and non-human beings. Within the ambit of environment, a host of ecosystems are functioning in which particular groupings of life forms interact with the environmental segments (R. Swarup, S.N. Mishra, V.P. Jauhar, 1992: 360). The word "environment" and its' synonym "surroundings", represents all conditions, circumstances and influences affecting the development of an organism. It particularly includes every living thing like human beings, animals and plants and non-living thing i.e. soil, water, light, climate temperature and pressure found on our planet. Environment is the complex of physical, chemical, and biotic factors that act upon an organism or an ecological community and ultimately determine its form and survival (G T Miller: 2004). The term 'environment' refers to all 
external conditions and factors that affect living organism. Here external factors mean all the things around us such as - air, water, light, animals, humans etc (Miller, G Tyler, Jr. 2002: 3).

Environment is the natural surroundings in which we and all living creatures live. While by "environmental pollution," we mean the dirtying and spoiling of these natural surroundings. The air is polluted, the seas are polluted, the ozone layer is diminishing and animal species are becoming extinct. Pollution of the social environment should be added to these: poverty, deprivation, homelessness, migration problems, racism, abandoned children, drug abuse, alcohol addiction, and other problems. Many contemporary thinkers and scientists have stated that religion has an important role to play in overcoming these problems and in the development of comprehensive and integral environmental consciousness.

According to Islam, everything in the universe is created by God. It is God Who adorns the skies with the sun, the moon and the stars, and the face of the earth with flowers, trees, gardens, orchards, and the various animal species. It is again God Who causes the rivers and streams to flow on the earth, Who upholds the skies (without support), causes the rain to fall, and places the boundary between night and day. The universe together with all its richness and vitality is the work and art of God, that is, of the Creator. It is again God Who creates all plants and animals as pairs, in this way causing their procreation.

\section{B. The Natural Order in Islam}

The roots of Islamic environmental practice are to be found in the Qur'an and the guidance of Prophet Muhammad. The Qur'an also asks us to be just to our natural surroundings, "We did not create the heavens and earth and everything between them, except with truth" (Qur'an, 15: 85). The Qur'an again uses an environmental theme in exhorting humankind to be moderate (Qur'an, 6: 142).

As the Islamic tapestry unfolded in its expression over the centuries, we discover that there are no references to the environment, as we understand it today. The word nature, which is an abstraction, cannot be found in the Qur'an 
and the closest modern Arabic usage is the word $b i^{\prime} a$ which connotes a habitat or a surrounding. The word nature will continue to be used in this essay for linguistic convenience. Islam insistently draws our attention to this sacred and spiritual dimension of nature. It teaches us too that we are created by God and that we shall return to Him in order to give account for our actions. This means that we are answerable for all that we do, both the good, and the evil. As God's vicegerent on earth, at the Last Judgments man will be called to account for how he acted towards the trust, and how he treated it. Islam looks at the environment from the standpoint of balance. It envisions the environmental balance as a part of the universal 'grand balance'. The Quran describes the notion of environmental balance in various terms like 'adl', 'qadar' and 'mouzoon'. The term 'adl' literally means acting justly, rightly, or equitably. While explaining the meaning of 'adl', one interpreter of the Quran has observed that the universe has been created in balanced form. Similarly, most of the early interpreters interpret the term, 'mizaan' in the meaning of 'adl'. Some other terms 'haq' and 'qist' have also been interpreted to have the same meaning. All of these terms, therefore, support the notion of environmental balance.

The Quranic term 'qadar' gives even more direct meaning of the environmental balance. The literal meaning of 'qadar' is a specified measure or amount either of quantities or qualities. This term corroborates the notion of balance in the following ayah: "Verily all things, we have created in proportion and measure." The above ayah makes a general statement about the existence of equilibrium in everything. The process of creation and growth of all things follows the principle of balance which, in the above ayah, has been referred to as 'proportion and measure. The notion of environmental balance is further supported by another term 'mouzoon' which occurs in the first of the following ayahs: Creation or nature is referred to as the signs "Ayat" of Allah and this is also the name given to the verses of the Holy Qur'an. 'Ayat' means signs, symbols or proof of the divine.

The Holy Quran says: "And the earth we have spread out set therein mountains firm and immovable and produced therein all kinds of things in due balance. And we have provided therein means of sustenance 
for you and for those whose sustenance you are not responsible". The basic environmental elements: water, air, cattle, crops, pasture, and forests occupy vital importance in the Islamic value system. The Quran and sunnah stress on the preservation of both the quantity and quality of these elements. For instance, water has been regarded as a basic source of life.

\section{Divine Unity}

The concept of Divine unity is the basis and essence of Islam. Divine unity is apparent in the unity of humanity and of nature. God's vicegerents on the earth, the holders of His trust, are therefore primarily responsible for preserving the unity of creatures, the integral wholeness of the world, the flora and fauna, and wildlife and natural environment. Unity', trust and responsibility are the three basic concepts of Islam. These principles are at the same time the chief pillars of the Islamic environmental ethic. They form also the fundamental values taught by the Qur'an. The Qur'an draws our attention to nature and to the events that occur in it: The earth is also important in regard to the concept of mutual relations. Human beings are created from two of its elements: earth and water. Thus, if man becomes alienated from the earth, he becomes alienated from his very nature. He is not the lord and ruler of the earth; he is a humble member of it. The superior qualities and faculties he possesses require not that he irresponsibly consumes and destroys its beauties and resources, but that he acts in awareness of his great responsibility towards them.

The universe we inhabit is a sign of God's creation as is the environment of our innermost selves. This bonding of the cosmic to the subatomic is the deep ecology of Islam but it is not a relationship of equals as we can see in the hierarchy of the food chain dominated by Man. Whilst the primary relationship is that between the Creator and the rest of His creation. According to the Qur'an, on the other hand, nature reflects, just like a mirror, the power, beauty, wisdom and mercy of its Creator. The Qur'anic view holds that everything on the earth was created for humankind. It was God's gift "ni'mah" to us, but a gift with conditions nevertheless and it is decidedly not something that one runs and plays 
with. The earth then is a testing ground of the human species. The tests are a measure of our acts in its broadest sense. That is living in a way that is pleasing to Allah, striving in everything we do to maintain the harmony of our inner and outer environments.

Islam is a universal religion and its concern for the environment is a universal one, cutting across national, religious and geographical barriers. Its major commandments are directed, not to the Muslims alone, but to the human race. The environmental worldview in Islam is a holistic one: it assumes a fundamental link and interdependency between all natural elements and bases its teachings on the premise that if man abuses or exhausts one element, the natural world as a whole will suffer direct consequences. This belief is nowhere formulated in one concise phrase; it is rather an underlying principle that forms the foundation of the Quranic teachings.

\section{The Importance of Cleanliness}

Islamic life is sensitive to the cause of environment. It is based on a set of values that enhance environmental consciousness of the Muslims. An Islamic society, therefore, produces environmental-friendly behavior which is quite helpful for maintaining the environmental balance. Islamic teachings attach high importance to cleanliness. Islam considers cleanliness to be one of the fundamentals of belief. It thus makes a direct connection between belief and cleanliness. It is because of this that throughout the age's cleanliness has been one of the Muslims' most striking characteristics.

In one Hadith, God's Messenger (PBUH) says: "Cleanliness is half of belief". Some of the earliest verses revealed to him by God were: "O, you wrapped up [in a mantle]! Arise and deliver your warning! And your Sustainer magnify! And your garments keep free from stain! And all abomination shun!" The clearest example of this approach in Islamic life may be seen in the Six Books of Prophetic Hadits, the chief and most reliable source of Islamic civilization. On looking at these books, it is seen that the sections on cleanliness come at the beginning. This shows clearly the priority the religion and civilization gives to cleanliness.

The Qur'an says: “O, you who believe! When you prepare for prayer, wash your faces, and your hands to the elbows; rub your heads [with water]; 
and wash your feet to the ankles. If you are in a state of ceremonial impurity, bath your whole body. The first condition of the obligatory prayers which are the foundation of Islam, the support of religion, and 'Ascension' of the believers is cleanliness. The Qur' an therefore commands that at least five times a day we wash those parts of the body that may become dirtied like the hands, face, nose, ears, mouth, neck, head, and feet, and that we keep them clean. The place the prayers are to be performed also has to be clean, as well as the clothes worn. Another dimension of the Islamic approach to cleanliness is apparent in the Divine Name of God's Most Beautiful Names (al-Asma al-Husna), the cleanness of the universe, and states that the face of the earth and such beings as the clouds, rain, flies, crows, maggots, earthworms, ants, various insects, and the red and white corpuscles in the human body all manifest the Name of Most Holy in their functions, and carry out duties as "cleansing officials." "God is beautiful and He loves the beautiful; $\mathrm{He}$ is generous and loves generosity; $\mathrm{He}$ is clean and loves cleanliness".

Throughout his life the Prophet Muhammad (PBUH) paid the greatest attention to cleanliness of every sort. For instance, he was always careful when going to the mosque or to visit someone or when being in the company of others to wear clean and presentable clothes, to rub fragrant scents on himself, and not to eat things like onion and garlic which would be unpleasant to others. It is clear then that Muslims are obliged to always be clean in every respect, both physical and moral and spiritual.

A Muslim who pays attention to physical cleanliness, that is, who keeps his body, house, and surroundings clean, will not neglect the purity of his heart and spirit and his moral purity. It is not possible that he neglects these. We all know that the most important condition for protecting ourselves against illness is being clean and living in a clean environment. What preventative medicine tells us is nothing different to this. Also, we should never forget this admonition of the Qur'an: "God loves those who turn to Him constantly and He loves those who keep themselves pure and clean." Hence, the Islamic perspective on the environment rests on the belief that Allah is the Creator and Sustainer of the universe. The whole universe along with all of its factors has been created with perfect wisdom. 


\section{The Cleanliness of the Social Environment}

Environmental health is the cleanliness of the common environment. These are places such as roads, places of worship, schools, parks, children's playgrounds, stadiums, excursion spots and picnic places, public lavatories, public beaches, and other such places. To maintain and cleanliness of the social environment is to think not of ourselves but of others. We should not forget that God's Messenger (PBUH) forbade the dirtying of the roads and paths people used, and the places they sat and rested, like shady places and under trees and walls. He said that to remove a branch or a thorn that would cause hurt to people as they passed was a part of belief. To pollute or dirty the city in which one lives, or the town or village and their surrounding countryside, waters, air, or views, and to scatter rubbish and refuse is both a sin and extremely discourteous. It is lack of thought both for oneself and for others.

For thoughtful people know that others will be disturbed by any place they have dirtied, and the beauties of nature spoilt. They are aware that it is an attribute of the believer and a sign of maturity not to leave scattered nutshells, bottles, cans, wrappers, and bits of paper and other refuse in the streets and public areas or to do anything that will disturb other people, or even the animals.

\section{The Preservation of Trees}

One of the most important aspects of protecting the environment and ecology is the conservation of the trees, forests, woodland, countryside, and all the living creatures whose habitats are such areas. Islam puts forward important principles for these too. These noteworthy principles related to the conservation of such areas may be classed as moral and legal. If we look at the Qur' an, we see that the word "tree" is mentioned with various meanings. Despite containing no direct command to plant trees, it speaks of trees and gardens and orchards so frequently and descriptively that it is not possible for any attentive reader of the Qur'an not to grow in awareness of them.

God adorned it with trees and gardens and offered them for man's use. The word "tree" is mentioned 26 times in the Holy Qur' an and the 
word "paradise" in the sense of garden came 146 times. The Holy Quran says: It is He Who sends down rain from the skies; with it We produce green crops, out of which we produce grain, heaped up [at harvest]; out of the date-palm and its sheaths or spates come clusters of dates hanging low and near; and [then there are] gardens of grapes, and olives, and pomegranates, each similar in kind yet different [in variety]; when they begin to bear fruit, feast your eyes with the fruit and the ripeness thereof. Behold! in these things there are signs for people who believe.

In another verse, the Holy Qur'an says: "It is He Who produces gardens, with trellises and without, and dates, and tilts with produce of all kinds, and olives and pomegranates, similar [in kind] and different in variety, eat of their fruit in their season, but render the dues that are proper on the day that the harvest is gathered. But waste not by excess; for God loves not the wasters. It is He Who sends down rain from the sky. From it you drink, and out of it grows the vegetation on which you feed cattle. With it He produces for you corn, olives, date-palms, grapes, and every kind of fruit. Verily in this is a sign for those who give thought.

These verses thus mention the rain, trees, earth, gardens, vineyards and date groves, and clouds; they point out the Divine balance between all the elements making up nature, and want us to take lessons from them. To put it another way, we are being required to raise our heads in our personal and daily lives and to look at the world about us in a different way. For through their order and systems and ecological balances, all creatures point to their Creator. In another place, the Qur'an draws our attention to the balance of nature, and then indicates that we should be careful to observe the balances and rights in the life of society. That is to say, rights and balances are universal rules that we have to observe.

The sun and the moon follow courses exactly computed, the herbs and the trees both a like bow in adoration. And the firmament He has raised high, and He has set up the balance of justice In order that you may not transgress [due] balance. So establish weight with justice and fall not short in the balance. It is clear that the Islamic world view could not endorse any view of man's vicegerency of the earth which destroys and 
spoils the ecological balances and the order and systems of nature, which it teaches that God has created and put as signs of His own existence. For vicegerent "khalifa" means 'deputy'. Man is the sole being whom God holds responsible for the earth, to which He has entrusted its preservation. Such a deputy would not betray the trust of the One who created the world with a particular order, balance, and harmony. If he was to spoil the order and harmony and destroy them, he would be known as an unreliable and perfidious deputy.

\section{The Protection of Animals}

Another important question related to the environment is the good treatment of the animals in our lives, and the protection of them; or more correctly, extending our kindness and compassion to them. However, today many animal species are becoming extinct. Other animals stray abandoned and hungry in the streets. Taken as a whole, therefore, it cannot be said that we treat animals well and carry out our duties towards them. In my view, one of the most important reasons for this is our indifference towards Islamic values. For Islam regulates not only relations between individuals and between individuals and society and the state, it also regulates relations between man and nature and man and the environment.

A natural consequence of this is that man is answerable to God for his attitude and actions towards nature and animals. This may be seen in the following Hadits of the Prophet (PBUH): If without good reason anyone kills a sparrow, or a creature lesser than that even, the living creature will put his plaint to God on the Day of Judgments, saying: 'Soand-so killed me for no purpose. It is thus stressed that the purposeless and arbitrary killing of the living creatures of nature, whether large or small, is prohibited, and that those who do so will be called to account by God on the Last Day.

\section{The Earth's Resources}

The Islamic principle related to the environment is the Islamic prohibition concerning thoughtless consumption; that is, wastefulness and 
extravagance. Wastefulness is not only the thoughtless consumption of natural resources; it is at the same time disrespectful towards God, the Creator and Owner of all the bounties. For this reason, in Islam, eating and drinking of licit food is lawful, but wastefulness is forbidden. At this time we know better than at any other that the world's resources are limited.

Extravagance and over-consumption will affect not only our selves, but forthcoming generations. We are therefore compelled to be aware and sensitive concerning this matter. In the Holy Qur'an, God says: "Verily, We have created all things in proportion and measure. If we keep this in mind, we see that carefully preserving the balance and measure is a human obligation. The science of ecology shows us that the universe contains extremely sensitive eco systems and balances, and that man has therefore to maintain these ecological systems. Now the man only came to realize the environmental problems with the help of ecology when the problems became apparent, whereas the Qur'an draws our attention to this balance in particular, which now everyone is trying to maintain.

The obligation of maintaining this balance, which is God's work, is men, whom God created on "the best of patterns", and who is His vicegerent or deputy on earth. No Muslim therefore will spoil the universe's balance, nor will any Muslim look on indifferently while other's spoil it. For the natural balance is at the same time a mirror reflecting Almighty God's Most Beautiful Names. Islam permits utilization of the environment, but this should not be arbitrary. Wastefulness and extravagance are prohibited by God: "O, children of Adam! Wear your beautiful apparel at every time and place of prayer; eat and drink, but waste not by excess, for God loves not the wasters". Thus, while utilizing the world's bounties, the Muslim should not do so with an unconstrained and irresponsible approach to consumption.

On the contrary, he is obliged to base all such actions and the measure of his consumption on Islamic economic principles. Every passing day it is becoming better understood that the world's resources are limited. The following commands of the Qur'an are striking at a time feasible development and economic models are being widely discussed:

The Qur'an commands us to eat and drink, but waste not by excess, for God loves not the wasters so that we become accustomed to 
avoiding wastefulness and extravagance in our daily consumption of food and drink. It frequently points out that frugality and consuming what one has without being over-lavished is the measure of what God loves. In some verses, Almighty God states that He "created every animal from water," showing in a most interesting and meaningful way that water is the basis of life and living.

The Prophet of Islam Mohammad (PBUH) also attached great importance to water, and forbade the excessive use of it even when taking the ablutions, saying that to do so was 'detestable' (makruh). He thus prevented people using too much water even for something like ablutions, when they are preparing to enter the Divine presence and court. A Hadits about this is the following: "the prophet Mohammad (PBUH) appeared while Sa'd was taking the ablutions. When he saw that Sa'd was using a lot of water, he intervened saying: 'What is this? You are wasting water." Sa'd replied asking: "Can there be wastefulness while taking the ablutions?" To which God's Messenger replied: "Yes, even if you take them on the bank of a rushing river". While interpreting this Hadith, Scholars have pointed out that it does not refer only to using less water while taking the ablutions, but to a basic principle of Islam. They have emphasized the following points in connection with it:

The Qur'an and the traditions of Prophet Muhammad stipulating that water is the basis of life lays a number of obligations and responsibilities on Muslims: the conserving of existent water supplies in the best possible way; the prevention of any activity that might lead to the pollution of water sources or spoil the purity and characteristics of the water; never adopting an extravagant and irresponsible attitude in the consumption of water; rational and regular utilization of water and water sources.

There are very good reasons for Islam prohibiting wastefulness and prodigality so forcefully. We may put it this way: there are between five and six thousand million people living in the world today. Just think of each individual person cutting down a tree or killing an animal just for the fun of it. Six thousand million trees or six thousand million animals would perish. Or think of the water they would waste, or the bread or other foodstuffs they 
would throw away. The serious consequences of those apparently insignificant actions are clear. Moreover, for the greater part it is not possible to reclaim the resources we have polluted, destroyed, or annihilated. It is in this light that we may understand how meaningful was the point God's Messenger (PBUH) was emphasizing when he said: "Even if you take the ablutions in a flowing river, do not waste the water," and how important it is for the preservation of the ecological balance.

\section{Conclusion}

The world belongs to all of us. We are all obliged to conserve and protect. We must co-operate and work together for a better world, a better future, and a better environment. We must love and preserve our environment and all the living creatures within it in the name of our Sustainer, Who created them and entrusted them to us. In this way, the $21^{\text {st }}$ century will be the century of peace, happiness, tolerance and brotherhood. The holy Quran is a primary source of knowledge for Muslims.' In fact, 'one of the basic and most important characteristics regarding social economy and the economic system upon which the Quran repeatedly lays stress is that all means and resources through which human beings earn their livelihood are divinely created.

Now the need of the hour is that the above said principle should be applied to human and environmental protection. It is noteworthy that the Islamic strategy for dealing with environmental problems is different from the secular approach. The teachings of holy Quran and Sunnah are giving equal importance to plants, trees, and agriculture as centre to life. In the Islamic teachings, the protection of environment is extremely important. The religious aspect of environment education is no less important than the scientific knowledge and technology related to this sector.

This situation also highlights the fact that the technology alone is not enough to win the war against the forces responsible for degradation of environment. This would lead to environmental security, physical and spiritual development. These developments would promote environmental protection leading to a high level of human security which will provide a solid 
base for human development. Today, the Qur'an once more is ready to challenge the modern materialistic conception of nature and to suggest and provide a more comprehensive and holistic approach to developing an environmental ethical theory.

\section{Bibliography}

Chatel, Francesca De. (2003). "Prophet Mohammed: A Pioneer of the Environmentalism"

Encyclopedia Britanica, CD Rom Edition, (2004) G T Miller: Living in the Environment

Husaini, W. A. Islam ic Environmental Systems Engineering, (London: 1980).

Iqbal, Sir Mohammad (1958). The Reconstruction of Religious Thought in Islam, Lahore: The Ashraf Press.

Khalid, F. (1998). Islam, Ecology and the World Order. In Harfiyah A. H, Islam and the Environment. London: Ta-Ha Publishers Ltd.

Maududi, Abu Al Ala, Tafheem-ul-Quran, vol. 5, p. 251

Miller, G Tyler, Jr. (2002). "Living in the Environment-Principles, Connections and Solutions". 12th ed. USA: Brooks/ Cole - Wadsworth Thomson Learning. p. 3.

Musnad, ii, 22; Ibn Maja, Tahara, 48, No: 425; i, 147.

Nasr, Seyyed Hossein (1997). Man and Nature, Chicago: Kazi Publications.

R. Swarup, S.N. Mishra, V.P. Jauhar (1992), p. 360

The Holy Qur'an. (1983). Trans. Yusuf Ali Maryland: Amana Corp., 1995) and also A.A. Razwy' edition, New York: Tahrike Tarsile Qur'an Inc.

ZA, T. (2014). Islamic Studies dalam Pendekatan Multidisipliner (Suatu Kajian Gradual Menuju Paradigma Global). Jurnal Ilmiah Peuradeun, 2(2), 211-234. 